\title{
AMOR E GÊNERO A SERVIÇO DO CASAMENTO BURGUÊS EM SENHORA, DE JOSÉ DE ALENCAR
}

Greiciellen Rodrigues Moreira ${ }^{1}$

\section{LOVE AND GENDER IN THE SERVICE OF BOURGEOIS MARRIAGE IN SENHORA, BY JOSÉ DE ALENCAR}

\section{Resumo}

Este artigo é parte da dissertação de mestrado "Representações femininas e identidade nacional: uma leitura alegórica de Lucíola e Senhora, de José de Alencar", desenvolvida no Mestrado em Estudos Literários da UNIMONTES. Em Senhora, nota-se, por meio das representações de gênero e de uma nova concepção pragmática sobre o amor, que José de Alencar apregoa um ideal burguês. Neste estudo, portanto, pretendeu-se evidenciar como o casamento burguês é representado na narrativa, observando-se o destaque que o romancista dá ao amor higiênico, uma vez que a sexualidade é vista sob uma nova perspectiva pelos higienistas oitocentistas, que atribuem a ela um papel fundamental para a saúde da família burguesa higienizada. A mulher é um elemento transformador na narrativa, uma vez que é por intermédio dela que o homem amado passa por um processo de aburguesamento.

Palavras-chave: Senhora. José de Alencar. Burguesia. Representações de gênero.

\section{Abstract}

This article is part of the dissertation "Representations of women and national identity: an allegorical reading of Lucíola and Senhora, by José de Alencar", developed by the Master of Literary Studies from UNIMONTES. In Senhora, José de Alencar proclaims a bourgeois ideal through the representations of gender and a new pragmatic way to understand love. Therefore, this study aims to show how the bourgeois marriage is represented in the narrative, noting the highlight about the hygienic love, since sexuality is seen from 
a new viewpoint by nineteenth-century hygienist doctors. They ascribe to sexuality a key role for the health of the hygienic bourgeois family. The woman is the element in the narrative that makes changes possible, since it is through her that the man she loves becomes a bourgeois man. Keywords: Senhora. José de Alencar. Bourgeoisie. Representations of Gender.

\section{Introdução}

Em “Escritoras, Escritas, Escrituras”, Norma Telles ressalta o papel fundamental que os produtos culturais, especialmente o romance, desempenham na cristalização da sociedade moderna. Segundo a autora, escrita e saber "estiveram, em geral, ligados ao poder e funcionaram como forma de dominação ao descreverem modos de socialização, papéis sociais e até sentimentos esperados em determinadas situações" (TELLES, 1997, p. 401-2). Telles assinala que o romance substitui a tradição das formas de ficção anteriores, que possuíam um direcionamento coletivo. A orientação do romance é original e individualista, ou seja, cada romance se debruça sobre uma entidade individualizada, particularizada para cada momento histórico: "É o romance que difunde a prosa da vida doméstica cotidiana, tendo como tema central o que os estudiosos contemporâneos denominam 'o romance da família', contribuindo assim para a construção da hegemonia do ideário burguês" (TELLES, 1997, p. 402).

O romance insere-se no discurso dominante oitocentista, atuando como difusor dos princípios burgueses. Contudo, não há no Brasil uma burguesia plenamente estabelecida em fins do século XIX; por isso, ao invés de simplesmente "descrever" modos de socialização, este estudo trabalha com a ideia de que em Senhora, José de Alencar oferece ao leitor "representações sociais" burguesas da sociedade carioca. É importante esclarecer que não é uma mera questão de escolha vocabular entre "descrever" e "representar". A razão de neste trabalho preferir-se o termo "representar" é devido às particularidades do conceito de representações sociais tal como é definido por Denise Jodelet. Segundo a autora, sempre há 
necessidade de estarmos informados sobre o mundo à nossa volta. Além de nos ajustar a ele, precisamos saber como nos comportar, dominá-lo física ou intelectualmente, identificar e resolver os problemas que se apresentam: é por isso que criamos representações. [...] Elas nos guiam no modo de nomear e definir conjuntamente os diferentes aspectos da realidade diária, no modo de interpretar esses aspectos, tomar decisões e, eventualmente, posicionar-se frente a eles de forma defensiva (JODELET, 2001, p. 17).

Jodelet argumenta que as representações sociais circulam nos discursos, são trazidas pelas palavras e veiculadas em mensagens e imagens midiáticas, cristalizadas em condutas e em organizações materiais e espaciais. A autora assim as define: "forma de conhecimento, socialmente elaborada e partilhada, e que contribui para a construção de uma realidade comum a um conjunto social" (JODELET, 2001, p. 22). As representações sociais são, então, sistemas de interpretação que regem a relação do sujeito com o mundo e com os outros sujeitos, ao passo que orientam e organizam as condutas e as comunicações sociais.

Ademais, as representações sociais são "concomitantemente produto e processo de uma atividade de apropriação da realidade exterior ao pensamento e de elaboração psicológica e social dessa realidade" (JODELET, 2001 , p. 22). Elas comportam uma parte de reconstrução, de expressão do sujeito e de interpretação do objeto ao qual o sujeito se reporta; além de receberem um papel criador no processo de elaboração da conduta. Portanto, compreender as representações sociais é fundamental para que se entenda o engendramento feminino no romance de Alencar, tendo em vista que, como afirma Teresa de Lauretis, gênero é a representação

de uma relação, [...] o gênero constrói uma relação entre uma entidade e outras entidades previamente constituídas como uma classe, uma relação de pertencer; assim, o gênero atribui a uma entidade, digamos a uma pessoa, certa posição dentro de uma classe, e portanto uma posição vis-à-vis outras classes pré-constituídas. (LAURETIS, 1994, p. 209).

Em suma, gênero representa não um indivíduo e sim uma relação social, ou seja, representa um indivíduo por meio de uma classe. Desse modo, gênero não é sexo, uma condição natural, mas a representação do sujeito 
em termos de uma relação social pré-existente ao próprio sujeito e predicada sobre a oposição "conceitual", rígida e estrutural dos dois sexos biológicos. Esta estrutura conceitual é o que, de acordo com Lauretis, cientistas sociais feministas denominam "o sistema de sexo-gênero": "um sistema de representação que atribui significado (identidade, valor, prestígio, posição de parentesco, status dentro da hierarquia social etc.) a indivíduos dentro da sociedade" (LAURETIS, 1994, p. 212).

Neste estudo, discutir-se-á a relação entre o engendramento feminino e o discurso burguês, uma vez que durante o século XIX projeta-se a construção de uma imagem do ser mulher que supra as necessidades do sistema burguês, ou seja, mulher destinada ao matrimônio e à maternidade, devendo ser boa esposa, administradora racional do lar e educadora dos filhos. Norma Telles afirma que no século XIX, o público leitor dos romances constitui-se em grande parte de mulheres burguesas. Nos romances, a figura feminina é representada ora como a ajudante do homem, a educadora dos filhos, um ser de virtude, o anjo do lar, ora como uma mulher fatal e decaída. Assim, de acordo com o discurso burguês oitocentista, quando encarna os ideais burgueses, a figura feminina é vista como força do bem, mas, se o oposto ocorre, e vai de encontro a esses ideais, se não aceita seu papel submisso, é caracterizada como potência do mal. Telles postula que, excluídas de

uma efetiva participação na sociedade, da possibilidade de ocuparem cargos públicos, de assegurarem dignamente a sua própria sobrevivência e até mesmo impedidas do acesso à educação superior, as mulheres no século XIX ficavam trancadas, fechadas dentro de casas ou sobrados, mocambos e senzalas, construídos por pais, maridos, senhores. Além disso, estavam enredadas e constritas pelos enredos da arte e ficção masculina. Tanto na vida quanto na arte, a mulher no século passado aprendia a ser tola, a se adequar a um retrato do qual não era a autora. As representações literárias não são neutras, são encarnações "textuais" da cultura que as gera. (TELLES, 1997, p. 408).

A mulher é enredada não apenas pelo discurso da ficção romântica, mas também pelo discurso médico, o qual, no século XIX, corrobora muitas das ideias sobre a fraqueza e a inferioridade feminina representadas nos romances. O engendramento feminino se dá em todos os campos, na arte e 
na ciência há uma preocupação constante em representar o ideal da mulher burguesa. Os médicos higienistas ${ }^{2}$ empenham-se com afinco na tarefa de formar a "mãe burguesa", empreendendo campanhas para convencer as mulheres a amamentar, retirando essa função das negras amas-de-leite, ao alegarem que não só doenças, mas a própria perversão dos escravos é passada para a criança através do leite (ALENCASTRO, 1997, p. 65).

Visam também à "mãe educadora" sob vigilância do médico da família. A mulher não deveria ser uma intelectual, mas precisaria ser inteligente o suficiente para administrar racionalmente o lar e os criados e educar os filhos. Doçura e indulgência são características que lhe são atribuídas para demonstrar a inferioridade feminina em relação ao homem. O cérebro feminino, acreditam os higienistas, é dominado pelo capricho ou instinto de coqueteria. Segundo Jurandir Freire Costa, constatava-se que

a mulher era mais frágil fisicamente que o homem. Dessa fragilidade, inferia-se a delicadeza e a debilidade de sua constituição moral, com a ajuda dos estereótipos correntes sobre a personalidade feminina. Procedimento semelhante era usado na descrição da "natureza" masculina. A "força" e o "vigor" migravam do físico ao moral, marcando os traços sócio-sentimentais da personalidade do homem. O amor, colocado no vértice de confluência das características físicas e morais, servia de referência à distinção entre os sexos. (COSTA, 1999, p. 235).

Possuidora de uma constituição tão frágil, para que não adoeça, é necessário que se submeta ao comando do homem e se dedique inteiramente à maternidade e à família. Conforme assinala Michelle Perrot, a "mulher, origem do mal e da infelicidade, potência noturna, força das sombras, rainha da noite, oposta ao homem diurno da ordem e da razão lúcida, é um grande tema romântico" (PERROT, 1992, p. 168). Desse modo, observa-se nos diferentes discursos que circulam na época que ser "pai e ser mãe passou a ser a finalidade última do homem e da mulher" (COSTA, 1999, p. 238).

Além da arte e da medicina, a filosofia também propicia o engendra-

2 O Higienismo é uma doutrina nascida do Liberalismo na primeira metade do século XIX. Segundo Jurandir Freire Costa, a higiene incorpora a cidade e a população ao campo do saber médico, ou seja, "a saúde passa a ser problema social" (COSTA, 1999, p. 33). Tudo o que diz respeito à saúde e ao bemestar da população passa, então, a ser objeto de interesse do médico oitocentista, o higienista: a pro criação, o bem-estar de mãe e criança, a prevenção de acidentes, o controle e prevenção de epidemias, entre outros. 
mento da mulher como criatura frágil, passiva, submissa, emotiva e instável.

A esse respeito, vale destacar a obra filosófica Emílio, ou Da Educação, escrita em 1762 por Jean-Jacques Rousseau. Apesar de ter sido escrita um século antes do romance abordado neste trabalho, esse livro é uma bibliografia fundamental para se entender o ideal burguês de comportamento de gênero, devido à preocupação de Rousseau com a formação dos sujeitos e ao papel fundamental de seus escritos para a ascensão da burguesia na Europa.

Comentando sobre o esforço filosófico da burguesia, Régine Pernoud ressalta a importância da obra de Rousseau para uma nova maneira de se pensar o homem, uma vez que o filósofo passa a considerá-lo do ponto de vista afetivo, valorizando, ao lado da razão, os "direitos do sentimento" (PERNOUD, 1973, p. 115-116). Destaca-se que os livros de Rousseau, assim como quase toda literatura de língua francesa, possuem grande influência na cultura brasileira oitocentista, pois como alega Emília Viotti da Costa, em "Alguns aspectos da influência francesa em São Paulo na segunda metade do século XIX", na

\footnotetext{
história da cultura brasileira há um momento em que ela passa direta e nitidamente a sofrer influência da cultura francesa. Essa época é o século XIX. Durante anos e anos, inúmeros traços foram acrescentados à vida brasileira graças aos contatos com homens, costumes, idéias e coisas de procedência francesa (COSTA, 2000, p. 278).
}

Em nota de rodapé presente em $A$ solidão tropical, Lucia Helena assinala que José de Alencar, como os demais homens cultos da época, também é leitor de Rousseau, tendo em vista a menção ao filósofo na crônica "Folhas soltas: conversas com meus leitores" (HELENA, 2006, p. 37). Desse modo, conquanto não haja registros factuais de que Alencar possuía em sua biblioteca o livro Emílio, ou Da educação, pode-se encontrar várias alusões a este no modo como o romancista constrói as personagens e por meio da ideologia burguesa apregoada em Senhora.

Rousseau argumenta que a única certeza em relação às questões de gênero é de que tudo o que homem e mulher têm em comum pertence à espécie e tudo o que têm de diferente pertence ao sexo, ou seja, homens 
e mulheres são seres completamente diferentes, cujo equilíbrio da espécie depende exatamente de terem consciência dessa diferença e serem educados conforme suas particularidades: "Um deve ser ativo e forte, o outro passivo e fraco; é preciso necessariamente que um queira e possa; basta que o outro resista pouco" (ROUSSEAU, 2004, p. 516).

Percebe-se, então, que o discurso dominante do final do século XIX apregoa um modelo de mulher burguesa, cujo ideal é difundido na arte, na medicina e na filosofia. José de Alencar, homem de seu tempo, também difunde esse ideal em sua obra. Em Senhora, por meio das representações femininas e de uma nova visão sobre o amor, não mais completamente idílico, mas vinculado ao amor físico, Alencar apregoa o ideal burguês do matrimônio. Neste estudo, portanto, pretende-se evidenciar como o casamento burguês é representado na narrativa, observando-se o destaque que o romancista dá ao amor higiênico, pragmático, uma vez que a sexualidade é vista sob uma nova perspectiva pelos higienistas da época, que atribuem a ela um papel fundamental para a saúde da família burguesa higienizada.

Magali Engel postula que no "discurso médico sobre a prostituição, produzido no Rio de Janeiro entre 1845 e 1890, a sexualidade é definida como função orgânica vinculada à necessidade de reprodução da espécie e, portanto, como um dado da natureza humana" (ENGEL, 1986, p. 170). Acredita-se ser uma exigência fisiológica a satisfação do desejo sexual, por meio do prazer. No entanto, "o desejo produzido pelo instinto natural é visto, ao mesmo tempo, como necessidade e veneno para o corpo e, assim, de sua livre manifestação poderia resultar a destruição do organismo" (ENGEL, 1986, p. 170). A livre manifestação do desejo relaciona-se à ideia de excesso de prazer e/ou ausência da finalidade reprodutora, inserindo-se no espaço da sexualidade pervertida.

Opondo-se à prostituição, lugar da sexualidade doente e das perversões, o casamento é concebido pelo discurso médico oitocentista como "instituição higiênica e único espaço reconhecido da sexualidade sadia" (ENGEL, 1986, p. 171). Sendo que a sexualidade sadia caracteriza-se pela ideia de prazer moderado, ou seja, nem excessivo, nem ausente, o que garante a reprodução da espécie e não ameaça a integridade do corpo. Sendo assim, a cópula do homem com uma prostituta é definida como relação in- 
completa ou imperfeita, pois ainda que atenda a uma necessidade orgânica, ela é apenas parcial, pois há a ausência do amor. De acordo com Soares, o "amor, concebido como 'união do corpo e da alma', seria o principal elemento constitutivo da 'relação ideal', que não bastaria a si mesma, pois 'seu objetivo último seria a reprodução da espécie'” (SOARES, 1986, p. 165). O autor acrescenta, ainda, que a relação amorosa perfeita só se realiza pelo matrimônio, "ato de criação do 'casal perfeito"' (SOARES, 1986, p. 166). Desse modo, Soares alega que a

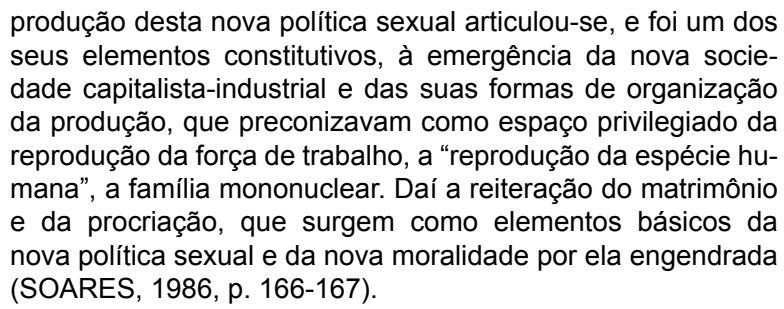

É importante ressaltar que essa política sexual já era adotada nos grandes centros europeus desde o século XVIII, mas no Brasil, os médicos e as autoridades apenas tentam implantá-la com afinco no limiar da desestruturação da sociedade escravista, momento de emergência de uma nova ordem industrial capitalista. Jurandir Freire Costa assinala que a redução da mulher ao papel de mãe e esposa devotada representa um compromisso entre o pai e o poder médico. Expropriado de terras, bens e escravos, o homem coloca seus genitais, por meio da higiene, a serviço do Estado. Em contrapartida, é-lhe dado o direito de concentrar toda a carga de dominação, antes distribuída sobre o grupo familiar e demais dependentes da propriedade, sobre a esposa, única propriedade privada que Ihe resta. Costa, então, conclui que de "propriedade jurídico-religiosa, a mulher passou a propriedade higiênico-amorosa do homem" (COSTA, 1999, p. 252).

Neste momento, vale destacar o questionamento que Eric Hobsbawn levanta em $A$ era do capital: "Por que deveria uma sociedade dedicada a uma economia de obtenção de lucro, livre iniciativa competitiva, esforços do indivíduo isolado, igualdade de direitos, oportunidades e liberdade, apoiar-se numa instituição que negava todos esses ideais?" (HOBSBAWN, 1996, p. 330-331). Hobsbawn argumenta que a família burguesa é uma autocracia 
patriarcal e um microcosmo de um tipo de sociedade que a burguesia, como classe, denuncia e intenta superar.

No lar burguês, entretanto, existe uma hierarquia de dependência pessoal, em que o homem encontra-se no topo da pirâmide, como pai, marido, senhor, guardião, guia e juiz. Abaixo dele e sob seu domínio está a mulher, anjo da casa, mãe, esposa e amante. Sua nova função de esposa burguesa é "ostentar a capacidade do marido burguês de mantê-la em paz e conforto" (HOBSBAWN, 1996, p. 331). Contudo, essa "escrava atraente, ignorante e tola era requisitada para exercer também dominação" (HOBSBAWN, 1996, p. 331), não sobre as crianças, cujo senhor é o pai, mas sobre os criados cuja presença distingue os burgueses dos que lhes são socialmente inferiores. Hobsbawn destaca que o "ponto crucial era o de que a estrutura da família burguesa estava em direta contradição com a sociedade burguesa. Dentro dela a liberdade, a oportunidade, o nexo do dinheiro e a busca do lucro individual não eram a regra" (HOBSBAWN, 1996, p. 332). Todavia, se a família burguesa parece uma contradição à sociedade burguesa, ela está, na verdade, em conformidade com o sistema econômico que possibilitou a ascensão da burguesia, o capitalismo. Segundo Hobsbawn, precisamente

porque não era baseada em desigualdades coletivas, institucionalizadas e tradicionais, a dependência precisava ser uma relação individual. Já que a superioridade era algo tão incerto para o indivíduo, ela precisava tomar uma forma em que fosse permanente e segura. Já que sua expressão essencial era o dinheiro, que reproduz meramente a relação de troca, outras formas de expressão que demonstrassem a dominação de pessoas sobre pessoas precisavam suplementá-la. Não havia evidentemente nada de novo na estrutura da família patriarcal, baseada na subordinação da mulher e filhos. Mas onde poderíamos esperar que a sociedade burguesa logicamente quebrasse a instituição ou a transformasse - como ela iria de fato se desintegrar mais tarde -, a fase clássica da sociedade burguesa reforçou-a e exagerou-a (HOBSBAWN, 1996, p. 333-334).

Então, observando-se a importância da família conjugal, das representações femininas e da nova visão sobre a sexualidade nos ideais burgueses, pretende-se evidenciar como o discurso burguês é representado em Senhora. Deseja-se analisar a forma como o discurso burguês de José de Alencar transparece no romance, por intermédio das representações de gênero. A 
mulher é um elemento transformador na narrativa, uma vez que é por meio dela que o homem amado, a princípio muito distante do ideal burguês do homem de bem, passa por um processo de aburguesamento, tornando-se dedicado ao trabalho, à moderação e à poupança.

\section{Os Pais de Aurélia: Pedro e Emília Camargo}

Pedro Camargo é o filho ilegítimo de um rico fazendeiro. Enquanto estuda na corte, conhece uma jovem chamada Emília Lemos, por quem se apaixona. No entanto, a família da donzela não concorda com a união do casal devido à condição bastarda de Pedro, que não possui direito à herança paterna. Emília tem a coragem para enfrentar sua família, decidindo casar-se secretamente com Pedro, mas a mesma atitude não pode ser esperada do rapaz. Apesar de amá-la e de casar-se com ela, Pedro "jamais se animaria a confessar o seu amor ao pai, que lhe inspirava desde a infância, pela rudeza e severidade da índole, um supersticioso terror" (ALENCAR, 2009, p. 86). Emília é uma habitante do meio urbano, onde as novas ideias chegam rápido e logo são incorporadas à vida pública, porém Pedro é habitante do meio rural, onde as inovações da cultura e da civilização chegam tardiamente e encontram resistência para modificar a estrutura social.

O discurso higiênico burguês desarticula as razões familiares em favor dos fatores higiênicos para a realização dos matrimônios. Segundo Jurandir Freire Costa, "o amor tornou-se necessário à higiene porque era um dos poucos estandartes morais disponíveis na luta contra os valores patriarcais. Em particular, na luta pelo direito de escolha afetiva e pessoal do cônjuge contra as razões do grupo familiar" (COSTA, 1999, p. 231). O direito de escolha individual da urbana Emília sobrepõe-se aos interesses familiares, e o amor do casal se concretiza em uma união conjugal. No entanto, Pedro ainda sofre grande influência do poder patriarcal, acovardando-se com a ideia de ter de enfrentar o pai.

Quando a notícia de que Pedro estava morando com Emília chegou ao conhecimento de Lourenço de Sousa Camargo, o fazendeiro ordenou que buscassem o filho imediatamente. Pedro deixa a esposa, prometendo retornar brevemente. Contudo, a covardia e fraqueza do rapaz se interpõem no 
caminho da felicidade dos enamorados, pois ele não teve "a coragem para afrontar novamente as iras do fazendeiro com a revelação do seu casamento. Preparava-se, fazia firme tenção; mas no momento propício fugia-lhe a resolução" (ALENCAR, 2009, p. 87). Emília sofreu devido a essa situação, mas nas cartas enviadas ao marido "nunca lhe escapou a menor queixa. Longe de exprobrar-lhe os receios, que a mantinham na incerteza de sua sorte, ao contrário o consolava do remordimento que sentia de sua própria timidez" (ALENCAR, 2009, p. 87).

Como assinala Luis Filipe Ribeiro, a relação de Emília e Pedro contém o tipo de desequilíbrio que estruturará toda a narrativa. "Ela é forte e bataIhadora; o marido, apesar de honrado, é fraco e covarde" (RIBEIRO, 1996, p. 161). A tolerância de Emília em relação à covardia do marido não é movida apenas por razões sentimentais, mas também por um objetivo prático. Ela sabe que o futuro do marido, filho natural, depende exclusivamente da vontade do pai, que poderia abandoná-lo na indigência se desejasse: "Esta circunstância influiu muito no espírito de Emília; não por si, que não tinha ambição: mas era esposa e mãe" (ALENCAR, 2009, p. 88).

Observa-se, assim, um verdadeiro desequilíbrio das funções sociais dos personagens. A fraqueza de Pedro contrasta com a força de Emília, em uma clara inversão das características apregoadas pelos higienistas. Enquanto o medo do pai faz com que Pedro acovarde-se, Emília, que ousara ir contra a vontade de sua família para casar-se com o amado, permanece firme ao seu lado e tolera a fraqueza do marido, movida não apenas pelo sentimento, como também pela razão.

No entanto, a força de Emília não advém de algum espírito inato de independência feminina, mas de seu papel de mãe. Michelle Perrot evidencia, em Os excluídos da história, que há no século XIX um reforço da figura da mãe nos meios populares urbanos (PERROT, 1992, p. 181). Sendo assim, a preocupação de Emília com o futuro dos filhos, Emílio e Aurélia, essa abnegação que é uma característica marcadamente feminina, é o que lhe dá paciência e tolerância para aceitar o inaceitável.

Emília também é obrigada a trabalhar para ajudar no sustento da casa. Embora a elite brasileira intente disseminar o ideal da mulher ociosa, totalmente dedicada à família, para todas as camadas sociais, não é um fato 
incomum que mulheres pobres tenham de trabalhar para se sustentarem e à sua família, atuando como costureiras, floristas, enfermeiras, entre outras ocupações (ENGEL, 1986, p. 185-186). Evidencia-se, então, que aquele que contribui determinantemente para o desequilíbrio dos papéis sociais do casal não é a mãe de Aurélia, mas seu pai, Pedro, cujo caráter fraco e irresoluto foge indubitavelmente ao ideal burguês masculino. Segundo Perrot, os

homens estão do lado da razão e da inteligência que fundam a cultura; a eles cabe a decisão, a ação e, conseqüentemente, a esfera pública. As mulheres se enraízam na Natureza; elas têm o coração, a sensibilidade, a fraqueza também. A sombra da casa lhes pertence (PERROT, 2005, p. 268-269).

Ainda que a ação e a decisão caibam ao homem, doze anos se passam sem que Pedro tenha coragem de contar sobre seu casamento ao pai. Um acontecimento, porém, forçará o jovem a tomar uma atitude. Lourenço dá um ultimato ao filho e exige que ele vá à fazenda vizinha a fim de formalizar o pedido de casamento feito em seu nome. Pedro parte, mas ao invés de ir à fazenda ou para a corte, hospeda-se em um rancho de onde não sairá com vida, pois seu espírito fraco cobra de seu corpo combalido o preço da luta moral que vivencia.

\begin{abstract}
A resistência à vontade do pai, a quem acatava profundamente, e as sublevações da sua consciência contra o receio de confessar a verdade, abalaram violentamente o robusto organismo desse homem forte para os trabalhos físicos, mas não feito para essas convulsões morais (ALENCAR, 2009, p. 89).
\end{abstract}

Acometido de meningite, sucumbe no rancho onde procurara abrigo. Nota-se na citação acima, uma relação conflitante corpo/espírito no que se refere à caracterização masculina oitocentista. Como se discutiu anteriormente, para a higiene do século XIX as "mulheres são doentes em seus corpos, em sua matriz, em seu cérebro, cuja própria estrutura exclui da criação" (PERROT, 2005, p. 269).

Sendo assim, as características físicas dos corpos feminino e masculino ressumam as características morais. Pedro Camargo, entretanto, apre- 
senta-se como uma exceção à regra. Apesar de possuir um corpo masculino fisicamente forte e robusto, sua constituição moral é feminina, ou seja, sensível, irresoluta, passiva e frágil. O resultado dessa desarmonia entre matéria e espírito é a morte, uma vez que a fraqueza moral sobrepuja o corpo viril. A partir da morte de Pedro Camargo, pode-se inferir que este novo e poderoso corpo social chamado burguesia necessita de uma constituição moral igualmente forte que se coadune com ele; temática sobre a qual o romance se debruça, apresentando um personagem moralmente corrompido, Fernando Seixas, que, no entanto, é resgatado pela instituição burguesa do casamento.

\section{Casamento burguês: sexualidade, amor e interesses}

Costa (1999) postula que, durante o período colonial, o contrato conjugal no Brasil baseia-se no intercâmbio de riquezas, o que é confirmado por certas práticas sociais a ele ligadas, como o dote. "Pelo dote, a mulher transferia ao marido parte dos bens de sua família de origem. A natureza eminentemente econômica da transação matrimonial tornou esta cláusula um requisito indispensável à sua efetivação" (COSTA, 1999, p. 217). Nesse contexto, a circulação de bens condiciona a circulação de mulheres, prescindindo-se do amor para se efetuar. Todavia, esses parâmetros mudam no decorrer do século XIX; as razões familiares são desarticuladas pelas razões higiênicas, e novas regras impõem-se ao contrato conjugal.

Em O desaparecimento do dote, Nazzari alega que o pacto matrimonial se altera em meados do século XIX, uma vez que a noiva não traz mais para o casamento dote algum, ou trazia apenas um pequeno dote. Consequentemente, o sustento dos recém-casados passa a depender cada vez mais da contribuição do marido, por meio de seus bens e de seu emprego, o que fortalece sua posição de negociador. Ao mesmo tempo, Nazzari afirma que "o casamento passou a ser encarado muito menos como uma questão de bens e muito mais como um vínculo pessoal entre indivíduos, tendo no amor seu motivo preponderante" (NAZZARI, 2001, p. 211).

Desse modo, o amor passa a exercer uma função fundamental na es- 
colha dos cônjuges. No entanto, ainda que esse novo elemento tenha adquirido especial importância nos enlaces matrimoniais, o dote e a condição social continuam a influenciar na escolha dos pretendentes, o que limita grandemente a possibilidade de uma jovem pobre e sem sobrenome como Aurélia Camargo, protagonista de Senhora, conseguir um marido, apesar de seus talentos. Expondo-se na janela de sua casa todas as tardes a pedido de sua mãe, a beleza de Aurélia logo se torna conhecida pela sociedade carioca, mas os pretendentes que lhe aparecem procuram por uma aventura, ao invés de um compromisso.

Moça de inteligência, ela logo nota as intenções de seus admiradores, mantendo-se impassível e alheia a todas as investidas. Contudo, essa situação muda com o aparecimento de Fernando Seixas. Ele se apaixona por Aurélia e a pede em casamento, porém o rapaz começa a "considerar praticamente a influência que devia exercer em sua vida esse casamento" (ALENCAR, 2009, p. 103), e após longa reflexão, chega à conclusão de que "suas posses não lhe permitiam por enquanto o casamento com uma moça bonita e elegante, naturalmente inclinada ao luxo" (ALENCAR, 2009, p. 103).

Evidencia-se, pois, que ainda que as razões higiênicas tenham desarticulado as razões familiares, as razões materiais continuam articulando casamentos. Seixas concebe o casamento por amor, já que não amaldiçoa o fato de ter se apaixonado, sendo levado ao pedido de casamento, entretanto, a ideia de ter de levar com sua esposa uma vida mais austera o aterroriza. O que ele recrimina em seu comportamento é ter se apaixonado por uma moça pobre e quase órfã, pois deseja amar apenas quem lhe convenha.

Quando Seixas vê-se diante de pretendente mais abastada, a Amaralzinha, o fator econômico uma vez mais faz o rapaz hesitar diante da ideia de matrimônio. Se o casamento com Aurélia o aterrorizava devido à pobreza da jovem, a união com a Amaral o amedronta devido à excessiva riqueza da moça, pois teme que não seja capaz de sustentar os hábitos de uma mulher elegante. Percebe-se que o caráter irresoluto de Seixas sempre o coloca em conflito quando se trata da instituição burguesa do casamento.

Como ocorrera com Pedro Camargo, Seixas contraria o ideal do homem burguês de atitude e decisão, e fica à espera que alguma emergência 
feliz resolva seu futuro. A emergência que muda seu destino é desencadeada pelo inesperado casamento da irmã. Impossibilitado de oferecer o dinheiro do dote de Nicota, decide aceitar uma proposta de se casar com noiva ignota, mas milionária, mediante adiantamento de parte do dote. Revela-se, posteriormente, que essa noiva se trata da agora rica herdeira Aurélia Camargo. Neste momento, é preciso que se destaque um trecho de diálogo entre Aurélia e Fernando:

- Nada lhe falta portanto.

- Diz meu tutor que me falta um marido; e ele incumbiu-se de o escolher.

- Qualquer?... É-lhe isto indiferente? Perguntou Seixas sorrindo.

- Está entendido que só aceitarei o que me agradar; mas não quero ter o aborrecimento de ocupar-me com semelhante assunto.

- Tão pouco lhe interessa!

- Ao contrário; tanto receio que tenho de comprometer eu mesma o meu futuro, que o confio à sorte. Deus proverá (ALENCAR, 2009, p. 69).

O receio que Aurélia diz ter em comprometer ela mesma seu futuro encontra embasamento na realidade dos casamentos por amor. Evidencia-se na afirmação da personagem o lado desvantajoso da livre escolha dos cônjuges. Costa postula que, nessas uniões, deposita-se no indivíduo a culpa por eventuais fracassos da relação conjugal: "Se o pressuposto do casamento por amor era a escolha individual, livre de injunções familiares, cabia ao indivíduo toda responsabilidade pela dissolução da família" (COSTA, 1999, p. 233).

A forte e determinada Aurélia sempre esteve disposta a arcar com essa grande responsabilidade, porém Fernando, acostumado a uma vida de luxos, de aparências e aos mimos familiares, é muito fraco e covarde para assumir esse compromisso sem o respaldo de uma grande fortuna. Sendo assim, somente o casamento com a agora milionária Aurélia, de quem fora uma vez enamorado, é capaz de possibilitar que Fernando aceite comprometer-se em matrimônio. Contudo, os devaneios de Fernando desfazem-se durante a noite de núpcias quando Aurélia revela o engodo do casamento: "Entremos na realidade por mais triste que ela seja; e resigne-se cada um ao que é, eu, uma mulher traída; o senhor, um homem vendido" (ALENCAR, 
2009, p. 82).

Os casamentos de conveniência continuam sendo realizados no decorrer do século XIX, não sendo incomum a união de jovens arrivistas com abastadas pretendentes. Todavia, ao interpelar Fernando e expor a natureza do contrato matrimonial, Aurélia rasga o véu da hipocrisia que encobria o evento, transgredindo o papel da mulher nos acertos conjugais, uma vez que ela não deveria ter, ou pelo menos precisaria fingir não possuir, conhecimento sobre os trâmites que concretizam a união.

Ribeiro argumenta que o acerto dos matrimônios nessa época geralmente depende do pai da noiva, pois os casamentos dos membros da classe alta oitocentista são um negócio entre homens. Desse modo, "às mulheres cabe um bem pequeno papel na articulação do casamento. O habitual era um pai a oferecer um dote - e, com ele, uma filha - e um noivo a aceitar os dois. A noiva só entra na história depois de selado o contrato e como objeto material da transação" (RIBEIRO, 1996, p. 152).

Todavia, a ascensão da classe burguesa e o aumento das populações dos meios urbanos possibilitam uma alteração na forma como se praticavam os arranjos matrimoniais. Segundo Nazzari, ao invés de arranjarem "o casamento de um homem e de uma mulher que nunca haviam se encontrado", como era feito durante o período colonial, as famílias passam a planejar frequentes "reuniões dos jovens que esperavam que se casassem, deixando o resultado por conta do processo natural do amor e da atração sexual" (NAZZARI, 2001, p. 215). É importante observar, porém, que apesar da "substituição generalizada do dote pelo amor como incentivo ao casamento [...] a vantagem material da obtenção imediata de bens por ocasião do casamento não iria deixar de ser uma consideração importante para um homem decidir casar-se" (NAZZARI, 2001, p. 216).

Ainda que a opinião da noiva passe a ser levada em consideração e que o dote esteja em gradual processo de desaparecimento, o corpo das mulheres continua não lhes pertencendo e o espaço das grandes decisões, das negociações e das discussões financeiras permanece como exclusividade dos homens. Afinal, como afirma Perrot, aos "homens, o público, cujo centro é a política. Às mulheres, o privado, cujo coração é formado pelo doméstico e a casa" (PERROT, 2005, p. 259). 
Aurélia não se sentiu traída quando o noivo a trocou por outra mulher, mas ao descobrir que a escolha do amado fora movida por interesses econômicos, decide, então, mais do que puni-lo pela quebra de seu ideal, exaltar seu amor negligenciado. A fim disso, ela transgride o papel da mulher oitocentista ao participar ativamente da negociação de seu próprio casamento, ainda que use um tutor em prol das aparências. Ela escolhe o marido/mercadoria, estipula o preço e retém o recibo.

Considerando-se a situação de Fernando e Aurélia, faz-se importante destacar que ainda que a ascendência dos parceiros ou sua posição social não constituam mais o principal fator para a união conjugal na segunda metade do século XIX, quando os parceiros pertencem a classes sociais diferentes, Rousseau alega que é importante que o homem seja de uma classe superior à da mulher, tendo em vista que como "a família só se liga com a sociedade através de seu chefe, é a condição do chefe que determinará a de toda a família" (ROUSSEAU, 2004, p. 598).

Segundo o filósofo, quando o homem casa-se com mulher pertencente à classe inferior à sua, ele eleva-a, sem se rebaixar. No entanto, casando-se com mulher de classe superior, rebaixa-a, sem se elevar. Ademais, "é da ordem da natureza que a mulher obedeça ao homem", então, quando ela advém de uma classe mais baixa, a ordem natural e a ordem civil se coadunam. Entretanto, casando-se com mulher de classe superior à sua, o homem vê-se diante da alternativa de "ferir seu direito ou seu reconhecimento, ser ingrato ou desprezado". Nesse caso, a esposa ganha uma autoridade que não lhe pertence, "torna-se tirana de seu chefe, e o senhor, transformado em escravo, vê-se reduzido à mais ridícula e à mais miserável das criaturas" (ROUSSEAU, 2004, p. 598). Neste último caso percebe-se bem a semelhança à situação de Aurélia, senhora, e Fernando, vendido/comprado.

Aurélia Camargo é uma mulher imperiosa, a qual comprara o homem que uma vez amara, para na noite de seu casamento humilhá-lo, desmascarando a farsa que é o casamento por interesses. Todavia, Aurélia não odeia o homem que a iludira, uma vez que ela sempre amou mais o ideal desse homem do que o homem em si. A revolta da jovem é contra a decepção pela quebra de seu ideal de amor. Segundo Mary Del Priore, no século XIX, ama-se 
porque todo o período romântico ama. Ama-se o amor e não propriamente as pessoas. [...] O amor parece ser, como foi com o livro de Rousseau no início, uma epidemia. Epidemia que, ao contagiar as pessoas, Ihes faz sofrer e suspirar no papel de apaixonadas. Tudo isso em silêncio, sem ação, se não as permitidas pela nobreza desse sentimento novo, suspirar, pensar, escrever e sofrer. Ama-se então, um conjunto de ideias sobre o amor (PRIORE, 2006, p. 215-6).

O apego de Aurélia ao seu ideal pode ser observado durante o episódio da pintura do retrato de Fernando. Ao receber a tela do pintor, ela fica desgostosa com a expressão fria e seca ali retratada. A fim de trazer à tona em Seixas o homem galante que amara, muda completamente sua conduta, criando em seu lar uma atmosfera de intimidade burguesa. Assim, quando o pintor termina o retrato, o que Aurélia vê "em face dela, destacando-se da tela, onde o pincel do artista o havia fixado com admirável felicidade", é "o homem que ela havia amado" a "sorrir-Ihe" (ALENCAR, 2009, p. 176).

Após conseguir seu intento, uma nova transformação opera-se no comportamento da personagem. Ela passa os dias fechada em seu quarto, e, quando aparece, está sempre distraída com o aspecto "dessas pessoas que se habituam a viver no mundo da fantasia, e que sentindo-se como aturdidas quando descem à realidade, refugiam-se em suas quimeras" (ALENCAR, 2009, 177). Como na descrição de Priore, Aurélia deixa-se envolver pelo ideal romântico fixado na pintura guardada no quarto. A jovem permanece em seus aposentos para pensar, sofrer e suspirar pelo homem representado na tela. Homem que, conquanto tenha a aparência de Seixas, não é o marido da jovem, mas a representação do colóquio amoroso por ela vivido no passado.

De acordo com Michelle Perrot, durante o século XIX há um esforço geral para delimitar os territórios do público e do privado, que ganham a consistência de esferas, as quais são pensadas como "equivalentes dos sexos e jamais a divisão sexual dos papéis, das tarefas e dos espaços foi levada tão longe" (PERROT, 2005, p. 459). A casa é o domínio das mulheres, portanto, o lugar onde Aurélia pode governar sem que isso se caracterize como transgressão. Entretanto, o lar de Aurélia, assim como seu casamento, é uma farsa da qual ela foge, refugiando-se no espaço mais privado de 
que dispõe, "a intimidade do eu, a câmara escura, a fortaleza do foro (forte) interior" (PERROT, 2005, p. 456).

Desse modo, o isolamento de Aurélia configura-se como uma transgressão dos deveres da esposa burguesa. A ação das mulheres, especialmente das esposas, consiste em "ordenar o poder privado, familiar e materno, a que eram destinadas" (PERROT, 1992, p. 180). Aurélia, porém, não somente transgride o ideal feminino ao assumir uma conduta imprópria para seu gênero, como também transgride o ideal de esposa, uma vez que se fecha em um mundo completamente privado para viver o idílio amoroso do passado enquanto negligencia seus deveres conjugais.

Contudo, assim como subitamente entrara nesse estado de delírio amoroso, Aurélia regressa de seu isolamento para lançar-se ao outro extremo. "Mostrava pelos divertimentos uma sofreguidão que nunca tivera, nem mesmo em solteira. Entrou a frequentar de novo a sociedade, mas com furor e sem repouso" (ALENCAR, 2009, p. 178). É possível perceber claramente o movimento da personagem que se lança do privado ao público, do amor idílico às paixões do mundo, do prazer espiritual ao contentamento do corpo físico. Ainda que suas atitudes pareçam antagônicas, elas representam bem o contraste inerente à concepção do amor higiênico, o qual, diferentemente do amor romântico, ideal, espiritual e etéreo, engloba uma dimensão material, a sexualidade humana. De acordo com Jurandir Freire Costa (1999, p. 226), até

o séc. $\mathrm{XIX}$, a sexualidade interferia muito pouco na estabilidade familiar. A solidez de um casal não dependia do nível de sexualidade que permeasse a relação. $O$ exercício sexual no casamento restringia-se à cópula com vistas à procriação. $\mathrm{O}$ sexo tinha um andamento conjugal oculto, isento de comentário público.

A higiene retoma a problemática sexual de modo diferente e com nova finalidade. Apesar de continuar a reprimir o prazer gratuito e irresponsável, passa a exaltar a sexualidade conjugal, assinalando um papel nevrálgico na coesão do casal e na concretização do casamento modelo. "O sexo, dentro da legalidade do matrimônio, tornou-se objeto de regulação médica, não por seus excessos mas por suas deficiências" (COSTA, 1999, p. 227). Incentiva-se a vida sexual das mulheres, cuja ausência ou debilidade comprometem 
a saúde física dos filhos e a moral do casal, e busca-se fixar a sexualidade masculina na relação com a esposa, a fim de livrá-la da prostituição ${ }^{3}$.

O ponto culminante da união conjugal é o amor, porém a cumplicidade com o romantismo sentimental tem limites, pois ao contrário do amor romântico, o amor higiênico é pragmático. Após meses de delírio romântico em seu quarto, o amor de Aurélia entra em uma nova fase, e seu corpo exige seus direitos higiênicos. Após o episódio do retrato, o erotismo passará a permear o relacionamento de Aurélia e Fernando, como se pode observar na cena que se passa entre o casal durante o regresso de um baile.

O contato com o corpo de Aurélia, sentada ao seu lado no carro, é uma tentação para Fernando, que fica incerto de suas atitudes. Neste momento, ele deseja esquecer tudo "só para lembrar-se que era marido dessa mulher e a tinha nos braços" (ALENCAR, 2009, p. 183), mas o breve pensamento de ousar algo contra Aurélia faz com que "um frio mortal" transpasse-lhe o coração, deixando-o inerte e com medo de si. "Todavia, ninguém sabe o que aconteceria se o carro não parasse tão depressa à porta da casa" (ALENCAR, 2009, p. 183).

A inquietação de Fernando é causada pelo intenso desejo por sua esposa. No passado, o rapaz se apaixonou pela inteligência, beleza, doçura e pureza de Aurélia, em nenhum momento demonstrou interesse pelo corpo da amada, ou seja, ele nutriu por ela um amor romântico, tendo em vista que ela possuía todas as virtudes dignas de serem admiradas. Entretanto, na situação atual, casado com ela, seu amor ganha direitos que não possuía quando solteiro. $\mathrm{O}$ amor higiênico torna o casamento o único lugar onde o sexo não somente é permitido, como incentivado. Sendo assim, ao desejar a esposa, Fernando está cumprindo seu papel higiênico no casamento, por esse motivo, seu desejo não é condenável.

O que impede que concretize suas ambições é a posição que ocupa na relação. A razão moral por trás do "frio mortal" é a honra ferida de homem "vendido". Ainda que ame Aurélia, Fernando é indigno desse amor, por isso

3 Conforme definição do período apresentada por Magali Engel, o termo "prostituta" caracteriza não só a mulher que publicamente mercantiliza os prazeres sexuais, como aquela que transvia das regras da honestidade e entretém relações ilícitas com mais de um indivíduo (ENGEL, 1986, p. 184). Objetivase com o combate à prostituição feminina debelar as doenças venéreas e prevenir o nascimento de filhos sifilíticos. 
teme que a força desse sentimento sobrepuje a razão e torne irremediável. a situação em que se encontra. Prosseguindo-se à cena da carruagem, a tentação continua:

O marido levou-a ao divã onde ela deixou-se cair prostrada [...]. Não tendo soltado logo o braço de Seixas, este reclinouse para acompanhar-Ihe o movimento, e achou-se debruçado para ela.

\section{$[\ldots]$}

Aurélia procurou a mão do marido e encostou-a na testa. Debruçando-se para ela com esse movimento, Seixas roçara com o braço o contorno de um seio palpitante. A moça estremeceu [...] e apertou [...] a mão do marido que ela conservara na sua.

\section{$[\ldots]$}

Ela ergueu de leve a cabeça, para vazar no semblante do marido a luz dos olhos, e sorriu. Que sorriso! Uma voragem, onde submergiam-se a razão, a dignidade, a virtude, todas essas arrogâncias do homem. (ALENCAR, 2009, p. 183-184).

Amor e erotismo confundem-se na cena supracitada. Octavio Paz alega que o amor é a atração por uma única pessoa, por um corpo e uma alma. Amor é escolha; erotismo, aceitação. "Sem erotismo - sem forma visível que entra pelos sentidos - não há amor, mas este atravessa o corpo desejado e procura a alma no corpo e, na alma, o corpo. A pessoa inteira" (PAZ, 1994, p. 34). Do mesmo modo, para os higienistas oitocentistas, o amor, sem a manifestação física no sexo, é apenas delírio. Quando Fernando decide partir, Aurélia indaga:

- Já? perguntou ela erguendo os olhos entre súplices e despóticos.

O marido estremeceu ao toque sutil dos dedos, que calcavamIhe docemente a palma da mão:

- Ordena que fique? disse com a voz trêmula.

- Não. Para quê?

O que exprimia essa frase, repassada do sorriso que lhe servia por assim dizer de matiz, ninguém o imagina (ALENCAR, 2009, p. 186).

Toda tensão do momento erótico vivenciado pelo casal resume-se nessa despedida, em que também fica evidente a posição conflituosa que os cônjuges ocupam nesse casamento ímpar. O olhar de Aurélia ao indagar o 
marido sobre a partida repentina é descrito por meio de duas qualidades antagônicas: súplice e despótico. Ela pergunta humildemente por que o marido deseja partir, subentendendo-se o desejo inerente de que ele permaneça ao seu lado. No entanto, sua pergunta também é despótica, ou seja, reflete a vontade absoluta de uma soberana que não admite que seu desejo seja contrariado.

Se por um lado Aurélia sente-se prostrada frente à veemência de seus sentimentos, por outro, sua posição de déspota de um marido vendido refreia seus instintos. Fernando, então, conhecendo seu lugar inferior nessa relação desigual, não pergunta à esposa se ela "pede" que fique, mas se ela "ordena" que permaneça. Todavia, ele o faz de modo trêmulo e incerto, pois também ele encontra-se dividido entre o desejo por essa mulher e as limitações de seu estado humilhante na relação.

A força dos interditos que separam o casal é colocada à prova durante uma valsa. Dante Moreira Leite assinala que toda "invenção social é percebida como potencialmente capaz de destruir a ordem humana existente em determinado lugar ou em certa época" (LEITE, 1979, p. 50), principalmente as invenções referentes ao corpo humano. No século XIX, a aproximação física entre os sexos é regulada por severas normas, por isso, uma inovação cultural que modifique esses padrões de proximidade desperta uma reação de curiosidade, mas também de prevenção contra a novidade.

De acordo com Dante Moreira Leite, uma "dessas inovações foi a valsa romântica. Se hoje os seus ritmos e suas intenções nos parecem despidos de qualquer sentido lascivo, não foi assim na época em que surgiu" (LEITE, 1979 , p. 50-51). A valsa representa uma situação quase única naquele século, permitindo que o casal se aproxime fisicamente e se isole dos outros, mas também representa uma situação de perigo real ou potencial devido a essa proximidade.

A valsa dançada por Aurélia e Fernando apresenta os elementos principais do amor higiênico. A proximidade dos amantes e o afloramento da sexualidade do casal, que, entretanto, envolve-se na "casta e santa auréola da graça conjugal" (ALENCAR, 2009, p. 202). Enquanto o par rodopia pelo salão, as sensações de Fernando tornam-se mais intensas, ao ponto de ele perder a consciência de si e sentir-se mesclar ao corpo de Aurélia. 
No momento em que Fernando recobra a consciência de si, pressentindo o perigo do deleite que o engolfava, ele intenta parar a dança. Contudo, Aurélia murmura-Ihe "uma palavra súplice": "Não!" (ALENCAR, 2009, p. 202). Note-se que a expressão de Aurélia, diferentemente da cena do divã, não se reveste de características antagônicas. Ela não ordena que o marido continue a dançar, ainda que pudesse exercer este poder, mas suplica-lhe que não pare, despindo-se de seu império e despotismo.

Esquecendo-se do destino que unira o casal, Fernando e Aurélia entregam-se à dança até que, em um rápido relance, o par se beija, e a valsa termina com o desfalecimento de Aurélia nos braços de Fernando. O beijo é a consumação do ideal com o material, do espiritual com o físico. A manifestação do amor em um ato prático. Como a amante que desmaia após atingir o gozo de unir-se ao amado, Aurélia desfalece ao finalmente encontrar em seu marido o ideal por quem se apaixonara. Todavia, com o fim da dança, todas as barreiras que os separam ressurgem. Para que o casal se una plenamente, Fernando deve recobrar sua liberdade de amar e ver-se livre da humilhante obrigação que lhe foi imposta ao vender-se no matrimônio.

\section{O aburguesamento de Fernando Seixas}

Único filho varão de uma família remediada do Rio de Janeiro, Fernando Seixas cedo é apresentado ao luxo e às vaidades da corte. "Enquanto Fernandinho alardeava nas salas e espetáculos", as mulheres de sua família "passavam o serão na sala de jantar, em volta do candeeiro, que iluminava a tarefa noturna" (ALENCAR, 2009, p. 45). Vivendo esse estilo de vida, sua moral é logo corrompida. No entanto, o casamento operará em Seixas uma imensa transformação, o que se reflete em seu comportamento profissional:

Grande foi pois a surpresa que produziu a assiduidade de Seixas na repartição. Entrava pontualmente às 9 horas da manhã e saía às 3 da tarde; todo esse tempo dedicava-o ao trabalho [...].

- Olha, Seixas, que isto é meio de vida e não de morte! [...].

- Vivi muitos anos à custa do Estado, meu amigo; é justo que também ele viva um tanto à minha custa (ALENCAR, 2009, p. 145).

Os colegas de trabalho estranham bastante a súbita mudança no comportamento de Seixas. A razão óbvia para essa transformação seria o ca- 
samento, o qual é considerado a iniciação do jovem na realidade da vida. "Ele prepara a família, a maior e mais séria de todas as responsabilidades" (ALENCAR, 2009, p. 45). No entanto, uma vez que esse "ato solene tem perdido muito de sua importância” (ALENCAR, 2009, p. 45), seus companheiros preferem atribuir esse novo comportamento do companheiro à riqueza recém-adquirida.

Todavia, o casamento é a explicação mais plausível para a mudança de comportamento de Seixas segundo os ideais burgueses. Jurandir Freire Costa postula que, para a higiene oitocentista, a natureza física e emocional do homem impele-o a ser pai. O homem é destinado ao trabalho, ao desempenho das forças físicas, ao uso do pensamento, a se servir da razão e do gênio para sustentar sua família, e, na execução dessa função, encontra sua mais alta expressão humana (COSTA, 1999, p. 238). De acordo com tese da Faculdade de Medicina do Rio de Janeiro, de 1842:

Esposo e Pai é quando o homem julga-se feliz; é quando a razão se esclarece mais e robustece as doutrinas moralizadoras do dever. É quando o homem deixa de ser uma simples alegria para os que os amparam e votaram-lhe carinho e amizade, e torna-se o chefe da família, símbolo da virtude e do respeito (VIANA, 1842 apud COSTA, 1999, p. 238-239).

A força da moral revitalizada de Seixas reflete-se em seus hábitos, dando-Ihe novo prestígio. Isso ocorre graças à instituição burguesa da união conjugal, a qual "levanta o homem do meio da humanidade onde se perdia confundido na multidão, dá-lhe foros de uma entidade cheia de prestígio e poder, concedendo-lhe as garantias mais seguras da vida física e moral" (VIANA, 1842 apud COSTA, 1999, p. 239). Por meio do matrimônio, Seixas passa por um processo de aburguesamento. Sua vida torna-se mais comedida, veste-se com elegância, mas simplicidade, conforme o ideal burguês da juste milieu, dedica-se ao trabalho honesto e à poupança.

Contudo, ainda que Fernando esteja passando por um processo de incorporação dos ideais burgueses, Aurélia, inicialmente, acredita que isso não passa de um capricho, e zomba do marido. Indignado com as afrontas e ironias da esposa, Seixas exclama: "A senhora tem uma sagacidade prodigiosa! Bem mostra que é sobrinha do Sr. Lemos" (ALENCAR, 2009, p. 154). Fernando Seixas não poderia ter proferido ofensa maior para Aurélia 
do que compará-la a Lemos, o tio que abandonou a irmã ao desamparo, que tentou aliciar a sobrinha para a prostituição, que reatou relações com a jovem movido exclusivamente pelo interesse na riqueza herdada por ela. $A$ dignidade ofendida e o "império de seu olhar de rainha" (ALENCAR, 2009, p. 154), foram suficientes para fazer Seixas arrepender-se de suas palavras.

A brandura com que Seixas se desculpa com a esposa, apesar das injúrias que esta lançara contra ele, evidencia a boa natureza de seu coração burguês. O homem de bem é racional e sensato, valendo-se "cada vez mais da diplomacia dos hábitos, estratégia mais adequada aos padrões da nova cidade" (COSTA, 1999, p. 249). Por esse motivo, a perda da razão, ainda que momentaneamente, causada por um excesso de fúria é motivo de vergonha e arrependimento imediato. Rousseau assinala que se o homem de bem é tomado pela cólera, agindo de modo a ferir o responsável por sua irritação, logo se arrepende do lapso da razão, movido pelo sentimento de culpa. Segundo o filósofo, quando "ele próprio é ofendido, no auge do furor, uma desculpa, uma palavra o desarma, e perdoa os erros do outro com o mesmo bom coração com que conserta os seus" (ROUSSEAU, 2004, p. 301).

Apesar da resistência inicial em acreditar na transformação de Fernando, Aurélia percebe, após algum tempo, a mudança que se opera no caráter do marido, "outrora frágil, mundano e volúbil", mas que, pouco a pouco, vai recuperando sua "natureza generosa" (ALENCAR, 2009, p. 212). Todavia, ainda há um obstáculo a ser superado para que o casal obtenha a felicidade. Fernando Seixas pode ter se transformado no homem burguês ideal, porém isso não é suficiente para garantir-lhe uma posição digna em um matrimônio em que entrou como mercadoria. É necessário, então, um último acerto de contas entre o casal.

\section{Considerações finais}

Uma noite, meses após o dia do casamento de Aurélia e Fernando, Seixas quita sua dívida com a esposa, devolvendo-lhe todo o valor do dote acrescido de juros. A interação do casal é descrita com indiferença, mas riqueza de detalhes matemáticos. O que é retratada não é uma conversa 
entre marido e mulher, mas o acerto de contas entre dois negociantes, a senhora e o vendido. Recobrada a honra e a integridade, Fernando sente que agora possui o direito de justificar a conduta que o levara ao casamento infame:

\begin{abstract}
- Ouça-me [...]. A sociedade no seio da qual me eduquei, fez de mim um homem à sua feição; o luxo dourava-me os vícios, e eu não via através da fascinação o materialismo a que eles me arrastavam. Habituei-me a considerar a riqueza como a primeira força viva da existência, e [...] o casamento era meio tão legítimo de adquiri-la, como a herança e qualquer honesta especulação. [...] Não somente vi-me ameaçado da pobreza, e o que mais me afligia, da pobreza endividado, como acheime o causador, embora involuntário, da infelicidade de minha irmã cujas economias eu havia consumido, e que ia perder um casamento por falta de enxoval. [...] Tudo isso abateu-me. Não me defendo; eu devia resistir e lutar; nada justifica a abdicação da dignidade. Hoje saberia afrontar a adversidade, e ser homem; naquele tempo não era mais do que um ator de sala; sucumbi (ALENCAR, 2009, p. 229).
\end{abstract}

Ressalta-se que o motivo que levou à "queda" de Fernando é previsto em Emílio, ou, Da educação, pois Rousseau adverte que o jovem cedo apresentado ao luxo, logo é corrompido por ele (ROUSSEAU, 2004, p. 312). A fim de conquistar a riqueza desde cedo ostentada diante de seus olhos, a dignidade e a moral embotam-se frente à possibilidade de um meio prático e rápido de ascensão, como o casamento. No entanto, no momento da enunciação, após passar por um processo de aburguesamento, a justificativa não é mais aceitável, pois ele acredita que se pudesse voltar ao passado, teria seguido um caminho diferente. Desse modo, a fala do personagem despe-se do tom de justificativa e reflete um alerta burguês, uma vez que o erro cometido por ele não é aceitável para a burguesia.

Quitada a dívida, extingue-se o infame laço matrimonial que unia Fernando à Aurélia, deixando-os livres para alcançarem a felicidade. Todavia, ainda que a riqueza de Aurélia tenha sido instrumento de regeneração para o marido, ao mesmo tempo ela os separara para sempre, já que a riqueza dela continua a dar-Ihe um poder superior ao do marido. Muriel Nazzari assinala que a "superioridade das esposas sentida pelos maridos provavelmente surgiu devido ao sistema do dote" (NAZZARI, 2001, p. 222), por essa razão, no decorrer do século XIX, há no Brasil manifestações de oposição a 
esse sistema, ainda que sua prática continue "em certa medida até o final do século e até mesmo fosse mencionada no Código Civil que entrou em vigor em 1917" (NAZZARI, 2001, p. 251-252).

Tendo em vista que Aurélia possui o dinheiro, consequentemente, 0 poder na relação, isso deixa Fernando em uma posição inferior e de submissão, ainda que a esposa jure-lhe amor e obediência. Ao ter se casado movido por interesses econômicos, Fernando já se rebaixara; se aceitar o amor da esposa, após o esforço para recobrar sua dignidade, ele não só continuará a se rebaixar, como também a rebaixará, já que o casal só se liga à sociedade por meio do marido (ROUSSEAU, 2004, p. 598).

Desse modo, a riqueza de Aurélia mostra-se como um obstáculo intransponível. Este problema, porém, já havia sido solucionado por ela no mesmo dia de seu casamento. Naquela data, Aurélia escrevera um testamento instituindo Fernando como seu herdeiro universal. Portanto, toda a riqueza do casal já pertence a Seixas, e o meio de o marido manter sua honra e dignidade é permitindo que a esposa viva a seu lado. $E$, assim, encerra-se o romance: "As cortinas cerraram-se, e as auras da noite, acariciando o seio das flores, cantavam o hino misterioso do santo amor conjugal" (ALENCAR, 2009, p. 231).

Observa-se em Senhora que Alencar fornece "dois argumentos contra o dote: um deles dirigido às mulheres, indagando se elas queriam ser amadas por si mesmas ou por seu dote; o outro, aos homens, sugerindo que não tinham dignidade se se vendiam por um dote" (NAZZARI, 2001, p. 252). Luis Filipe Ribeiro afirma que em "José de Alencar, o conflito passa sempre pelo casamento. Essa é a área da realidade sobre que ele se debruça com especial carinho, constituindo-a como centro motor da vida social” (RIBEIRO, 1996, p. 397). Assim como outros autores românticos, Alencar salienta em sua obra o valor do casamento por amor e enfatiza ser necessário que os homens deixem de ser devassos, que parem "de viver dissolutamente e de dedicar-se ao jogo", e que assumam "as responsabilidades de uma família por meio da ética do trabalho" (NAZZARI, 2001, p. 252-253).

Ainda que Fernando e Aurélia casem-se, a união só pode ser consumada quando Fernando tornar-se digno da relação, e o casamento por interesse puder se transformar em uma união por amor. Como Ribeiro alega, 
Alencar "está atento e vigilante para que a instituição do casamento não se deixe corromper, pondo em risco toda uma forma de vida e de sociedade" (RIBEIRO, 1996, p. 398).

Conclui-se, portanto, que em Senhora, Alencar apregoa um ideal de família burguesa, exaltando o casamento, o amor higiênico e a submissão feminina. Se a transgressão inicial de Aurélia, ao comprar o marido, foi necessária para que Fernando Seixas passasse por um processo de aburguesamento, o jovem casal somente encontrará a felicidade conjugal quando cada um introjetar as qualidades burguesas atribuídas ao seu gênero. A imperiosa, altiva e independente Aurélia submete-se ao marido ajoelhando-se aos seus pés. Seixas, por sua vez, deixa de ser o jovem de moral embotada e caráter irresoluto, para transformar-se no verdadeiro homem burguês, detentor da autoridade em seu lar e sobre sua esposa.

\section{Referências}

ALENCAR, José de. Senhora. 35. ed. São Paulo: Ática, 2009.

ALENCASTRO, Luiz Felipe de. Vida privada e ordem privada no império. In: NOVAIS, Fernando A. (Coord.); ALENCASTRO, Luiz Felipe de (Org.). História da vida privada no Brasil: Império. São Paulo: Companhia das Letras, 1997. 2. v. p. 11-93.

COSTA, Emília Viotti da. Alguns aspectos da influência francesa em São Paulo na segunda metade do século XIX. Rev. hist., São Paulo, n. 142143, dez. 2000. Disponível em: <http://www.revistasusp.sibi.usp.br/scielo. php?script=sci_arttext\&pid=S0034-83092000000100008\&lng=pt\&nrm=i so>. Acessos em: 03 fev. 2012.

COSTA, Jurandir Freire. Ordem médica e norma familiar. Rio de Janeiro: Edições Graal, 1999.

ENGEL, Magali G. O médico, a prostituta e os significados do corpo. In: VAINFAS, Ronaldo (Org.). História da sexualidade no Brasil. Rio de Janeiro: Edições Graal, 1986. p. 169-190.

HELENA, Lucia. A solidão tropical. Porto Alegre: EDIPUCRS, 2006.

HOBSBAWM, Eric J. A era do capital. Tradução de Luciano Costa Neto. Rio de Janeiro: Paz e Terra, 1996.

JODELET, Denise (Org.). As representações sociais. Tradução de Lílian Ulup. Rio de Janeiro: EdUERJ, 2001. 
LAURETIS, Teresa. Tecnologia do gênero. In: HOLLANDA, Heloísa Buarque (Org.). Tendências e Impasses: o feminismo como crítica da cultura. Rio de Janeiro: Rocco, 1994, p. 206-204.

LEITE, Dante Moreira. O amor romântico e outros temas. 2. ed. São Paulo: Editora Nacional, Editora da Universidade de São Paulo, 1979.

NAZZARI, Muriel. O desaparecimento do dote: mulheres, famílias e mudança social em São Paulo, Brasil, 1600-1900. Tradução de Lólio Lourenço de Oliveira. São Paulo: Companhia das Letras, 2001.

PAZ, Octavio. A dupla chama, amor e erotismo. Tradução de Wladir Pupont. 14. ed. São Paulo: Siciliano, 1994.

PERNOUD, Régine. As origens da burguesia. 2. ed. [S.I.]: Publicações Europa-América, 1973

PERROT, Michelle. As mulheres ou os silêncios da história. Tradução Viviane Ribeiro. Bauru/SP: EDUSC, 2005.

PERROT, Michelle. Os excluídos da história: operários, mulheres e prisioneiros. Tradução de Denise Bottmann. 2. ed. Rio de Janeiro: Paz e Terra, 1992.

PRIORE, Mary Del. História do amor no Brasil. 2. ed. São Paulo: Contexto, 2006.

RIBEIRO, Luis Filipe. Mulheres de papel: um estudo do imaginário em José de Alencar e Machado de Assis. Niterói: EDUFF, 1996.

ROUSSEAU, Jean-Jacques. Emílio, ou, Da educação. Tradução de Roberto Leal Ferreira. São Paulo. 3. ed. São Paulo: Martins Fontes, 2004. SOARES, 1986

SOARES, Luiz Carlos. Da necessidade do bordel higienizado. In: VAINFAS, Ronaldo (Org.). História da sexualidade no Brasil. Rio de Janeiro: Edições Graal, 1986. p. 143-168.

TELLES, Norma. Escritoras, escritas, escrituras. PRIORE, Mary Del (Org.); BASSANEZI, Carla (Coord.). História das mulheres no Brasil. 9. ed. São Paulo: Contexto, 2009, p. 401-442. 